\title{
Status Gizi, Eosinofilia dan Kepadatan Parasit Malaria Anak Sekolah Dasar di Daerah Endemis Malaria
}

\author{
M. Mexitalia, IGK Oka Nurjaya, Agus Saptanto, Moedrik Tamam, I. Hartantyo, \\ Ag. Soemantri \\ Bagian Ilmu Kesehatan Anak Fakultas Kedokteran Universitas Diponegoro/RS Dr. Kariadi Semarang
}

\begin{abstract}
Latar belakang. Interaksi antara infeksi, status gizi dan imunitas telah lama diketahui, tetapi penelitian tentang interaksi ini di daerah endemis malaria masih terbatas.

Tujuan. Bertujuan untuk mengetahui hubungan kepadatan parasit malaria dengan status gizi, kadar hemoglobin dan respon eosinofilia pada anak sekolah dasar di daerah endemis malaria.

Metode. Penelitian belah lintang pada anak SD yang dipilih secara cluster random sampling di Kabupaten Sumba Timur Nusa Tenggara Timur pada tahun 2003. Diambil data status gizi, kadar hemoglobin, kepadatan parasit malaria dan jumlah eosinofilia dari darah subjek.

Hasil. Dari 137 anak (57 laki-laki dan 83 perempuan) dengan rerata umur (11,5 $\pm 1,37)$ tahun, didapatkan gizi kurang 63,6\%. Tiga belas persen anak terdapat parasit malaria pada sediaan darah, eosinofilia pada $32,9 \%$ anak. Kepadatan parasit malaria tinggi 7,9\%. Kepadatan parasit malaria tidak berhubungan dengan jenis kelamin, suku bangsa dan status gizi, tetapi kepadatan parasit malaria tinggi meningkatkan risiko anemia 2,1 kali (RP 2,1; 95\% KI 1,6-2,8; p=0,006) dan tidak terjadinya respon eosinofilia 2,9 kali (RP 2,9; 95\% KI 1,9-4,2; $\mathrm{p}=0,001)$.

Kesimpulan. Sebagian besar anak mempunyai status gizi kurang. Kepadatan parasit malaria tidak berhubungan dengan jenis kelamin, suku bangsa dan status gizi. Tetapi kepadatan parasit malaria yang tinggi akan meningkatkan risiko anemia 2,1 kali dan tidak adanya respon eosinofilia 2,9 kali. (Sari Pediatri 2007; 9(4):274-80).
\end{abstract}

Kata kunci: status gizi, eosinofilia, anemia, kepadatan parasit, endemis malaria

\footnotetext{
Alamat korespondensi

Dr. M. Mexitalia, Sp.A(K) Bagian Ilmu Kesehatan Anak Fakultas Kedokteran Universitas Diponegoro / RS Dr. Kariadi. Jl. Dr. Sutomo 16 Semarang. Telp. / Fax. 0218414296 email : maria_mexitalia@yahoo.com
}

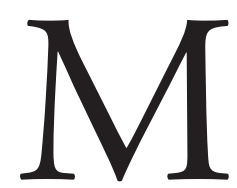

alaria merupakan penyakit endemis yang dijumpai di seluruh dunia, terutama di daerah tropis dan merupakan salah satu penyebab utama morbiditas dan mortalitas pada anak. ${ }^{1,2}$ Di Kabupaten 
Sumba Timur Propinsi Nusa Tenggara Timur, malaria merupakan penyakit endemis. Pada tahun 2001 dari 178.697 penduduk pada pemeriksaan sediaan darah didapatkan positif malaria 5.489 kasus, malaria falsiparum 2050, malaria vivax 3427, dan mixed 12 kasus. ${ }^{3}$ Berdasarkan spleen rate (SR) pada kelompok usia 2-9 tahun, endemisitas malaria di suatu daerah diklasifikasikan, 1) hipoendemik bila SR 10\%,2) mesoendemik bila SR 11\%-50\%,3) hiperendemik bila SR 50\% dan 4) holoendemik bila SR 75\% dengan SR pada orang dewasa $25 \%{ }^{4}$

Kelompok risiko terserang malaria adalah anak-anak dan wanita hamil terutama pada kelompok sosial ekonomi rendah. Dari beberapa penelitian diketahui bahwa anak dengan gizi kurang mempunyai prevalensi lebih tinggi untuk terinfeksi malaria, ${ }^{1,2,5}$ tetapi sebaliknya kurang energi protein (KEP) akan melindungi pejamu dari infeksi malaria. Pada penelitian di India ${ }^{1,2}$ didapatkan kasus malnutrisi mempunyai kepadatan parasit (plasmodium falsiparum), lebih rendah dari pada gizi baik, sedangkan di Nigeria didapatkan infeksi berat lebih sering pada anak gizi baik. Kematian karena malaria jarang terjadi pada anak malnutrisi.

Malaria juga akan meningkatkan prevalensi anemia dan berhubungan erat dengan defisiensi mikronutrien lainnya seperti seng dan vitamin A. ${ }^{1,6}$ Berdasarkan data Direktorat Gizi Departemen Kesehatan RI tahun 2003 didapatkan $12,5 \%$ gizi buruk pada anak balita di Nusa Tenggara Timur dan gizi kurang 25,93\%.7 Pada tahun 2001 malaria menyerang $12 \%$ anak usia sekolah di Sumba Timur. ${ }^{3}$

Imunitas terhadap malaria sangat kompleks karena melibatkan hampir seluruh komponen sistem imun. ${ }^{8-10}$ Imunitas penduduk yang tinggal di daerah endemis malaria berbeda dengan daerah non endemis. Pada daerah endemis malaria terjadi premunisi atau keadaan semi imun yaitu respon imun yang mampu menekan pertumbuhan parasit tidak sampai nol, mencegah hiperparasitemia, menurunkan kepadatan parasit malaria, dan menekan virulensi parasit sehingga tidak sampai menimbulkan gejala (asimptomatis). ${ }^{8,9,11,12}$

Peran eosinofil pada penyakit malaria belum banyak diungkap, selama ini lebih banyak dilaporkan peran Eosinofil pada reaksi alergi dan infestasi cacing. ${ }^{8,13}$ Stimulasi timbulnya eosinofilia terjadi akibat rangsangan limfokin yang diproduksi oleh limfosit $\mathrm{T}$. Eosinofil, histamin dan IL-8 meningkat pada pasien malaria. ${ }^{8-10}$ Eosinofilia dapat diketahui dengan pemeriksaan apusan darah yang merupakan bagian dari pemeriksaan darah rutin. Penurunan jumlah eosinofil dapat memberikan gambaran respon baik terhadap terapi malaria..,14

\section{Metode}

Telah dilakukan penelitian observasional dengan rancangan belah lintang, pada bulan Januari 2003. Anak Sekolah Dasar (SD) di daerah endemis malaria tinggi berdasarkan hasil surveilans tahun sebelumnya merupakan subjek penelitian. Terpilih SD secara cluster sampling yang termasuk dalam wilayah kerja Puskesmas Waingapu, Kambaniru dan Melolo. Semua anak SD sehat yang bertempat tinggal di daerah penelitian diikutsertakan dalam penelitian. Kriteria eksklusi adalah anak dengan gizi buruk, obesitas, anemia berat $(\mathrm{Hb}<8 \mathrm{~g} / \mathrm{dl})$, menderita defisiensi G6PD, ovalositosis, dan penyakit kronik lainnya selain malaria. Informed consent dimintakan kepada orangtua. Ijin penelitian disetujui oleh Dinas Kesehatan Kabupaten Sumba Timur, Nusa Tenggara Timur.

Pada subjek dilakukan pengukuran antropometri meliputi pemeriksaan berat badan dengan timbangan CEBA yang telah ditera, dengan tingkat ketelitian 100 gram. Tinggi badan diukur dengan mikrotoise dengan tingkat ketelitian $1 \mathrm{~mm}$. Indeks Masa Tubuh (IMT) dipakai sebagai parameter status gizi dengan memakai kurva CDC 2000 menurut umur dan jenis kelamin dan dikategorikan mengalami obesitas bila IMT $\geq$ persentil ke-95, berat badan lebih (overweight) bila IMT $\geq$ persentil ke-85 dan < persentil ke- $95,{ }^{15}$ gizi normal apabila IMT $\geq$ persentil ke- 5 dan $<$ persentil ke-85, dan gizi kurang apabila kurang dari persentil ke-5. Kategori gizi buruk apabila pada pemeriksaan antropometri didapatkan WHZ <-3 SD dan atau didapatkan pengurusan otot atau edema simetris. ${ }^{16}$ Dilakukan wawancara untuk mendapatkan data umur, riwayat penyakit dan dilakukan pemeriksaan fisik untuk mengukur pembesaran hati dan limpa.

Sampel darah diambil secara intravena, dibuat preparat darah tebal untuk pemeriksaan malaria dan hapusan darah tepi untuk pemeriksaan hitung jenis dan eosinofil. Sediaan darah tebal tidak difiksasi, langsung diberi larutan Giemsa selama 20 menit, kemudian dicuci dengan air yang mengalir dan dikeringkan. Sediaan darah tipis difiksasi dengan metanol selama 2 menit hingga kering, diberi larutan giemsa selama 20 menit (dengan perbandingan 10 
cc larutan buffer dan 1 cc larutan giemsa), kemudian dicuci dengan air yang mengalir dan dikeringkan. Pemeriksaan eosinofil dilakukan secara manual direk dari pemeriksaan darah tepi. Eosinofilia positif apabila eosinofil pada darah tepi lebih atau sama dengan 3\%.

Pemeriksaan kepadatan malaria dilakukan oleh tenaga terlatih di Balai Pengembangan dan Penelitian Vektor Malaria di Salatiga, Jawa Tengah. Kepadatan parasitemia dihitung berdasarkan jumlah parasit aseksual (stadium parasit) dibagi jumlah lapangan pandang yang diperiksa. Pemeriksaan darah tebal dilakukan dengan memeriksa 100 lapangan mikroskopis dengan pembesaran 500-600 yang setara dengan $0,20 \mu \mathrm{l}$ darah. Jumlah parasit dapat dihitung per lapangan mikroskopis dengan metode semikuantitatif untuk hitung parasit (parasit count) pada sediaan darah tebal. Ditetapkan negatif bila tidak ditemukan parasit dalam 100 lapangan pandang, positif 1 bila ditemukan $1-10$ parasit/100 lapangan pandang, positif 2 bila 11-100 parasit/ 100 lapangan pandang, positif 3 bila $1-10$ parasit/ lapangan pandang, positif 4 bila 11-100 parasit/ lapangan pandang). ${ }^{17}$ Dinyatakan kepadatan parasit tinggi bila didapatkan hasil $\geq$ positif 3 dan kepadatan parasit rendah bila didapat hasil $\leq$ positif 2 .

Kadar hemoglobin yang diukur menggunakan metoda cyanmethemoglobin menurut Ellers. Anemia bila kadar $\mathrm{Hb}$ di bawah $12 \mathrm{~g} / \mathrm{dl} .{ }^{18}$ Semua anak dengan anemia mendapat terapi tablet besi sesudah disingkirkan penyebab anemia. Anak dengan kadar $\mathrm{Hb}<8 \mathrm{~g} / \mathrm{dl}$ dikeluarkan dari analisis. Pemeriksaan defisiensi G6PD dilakukan dengan metode cincin Formazan di Department of Anthropology Faculty of Science University of Tokyo Japan, sedangkan ovalositosis disingkirkan dengan pemeriksaan hapusan darah tepi. Pemeriksaan tinja untuk mencari telur cacing dilakukan dengan cara memasukkan feses dan cairan $\mathrm{NaCl}$ jenuh, kemudian ditutup dekglas dan didiamkan selama 20 menit. Setelah itu dekglas diambil dan diletakkan di atas gelas

Tabel 1. Karakteristik sampel

\begin{tabular}{|c|c|c|c|c|}
\hline Variabel & $\begin{array}{c}\text { Laki-laki } \\
\mathrm{n}=57\end{array}$ & $\begin{array}{l}\text { Perempuan } \\
\mathrm{n}=83\end{array}$ & $\begin{array}{c}\text { Total } \\
\mathrm{n}=140\end{array}$ & $\mathrm{p}$ \\
\hline Umur (bulan); rerata(SB) & $11,7 \pm 1,36$ & $11,4 \pm 1,36$ & $11,5 \pm 1,37$ & $0,246 \ddagger$ \\
\hline Berat badan $(\mathrm{kg})$; rerata $(\mathrm{SB})$ & $26,1 \pm 4,59$ & $26,5 \pm 4,93$ & $26,3 \pm 4,78$ & $0,604 \dagger$ \\
\hline Tinggi badan $(\mathrm{m})$; rerata $(\mathrm{SB})$ & $132,5 \pm 8,68$ & $133,9 \pm 7,91$ & $133,3 \pm 8,24$ & $0,289 \dagger$ \\
\hline IMT $\left(\mathrm{kg} / \mathrm{m}^{2}\right) ; \operatorname{rerata}(\mathrm{SD})$ & $14,8 \pm 1,57$ & $14,7 \pm 1,90$ & $14,7 \pm 1,77$ & $0,822 \ddagger$ \\
\hline \multicolumn{5}{|l|}{ Hemoglobin $(\mathrm{g} / \mathrm{dl})$; rerata $(\mathrm{SB})$} \\
\hline Suku bangsa (\%) & $11,6 \pm 1,57$ & $12,2 \pm 1,93$ & $12,0 \pm 1,96$ & $0,091 \dagger$ \\
\hline - Sumba & 70,2 & 54,2 & 60,7 & \\
\hline - Non Sumba & 29,8 & 45,8 & 39,3 & $0,058 \ddagger$ \\
\hline \multicolumn{5}{|l|}{ Status gizi (\%) } \\
\hline - Gizi baik & 33,3 & 38,6 & 36,4 & \\
\hline - Gizi kurang & 66,7 & 61,4 & 63,6 & $0,530 \ddagger$ \\
\hline \multicolumn{5}{|l|}{ Kadar hemoglobin (\%) } \\
\hline - Normal & 45,6 & 57,8 & 52,9 & \\
\hline - Anemia & 54,4 & 42,2 & 47,1 & $0,156 \ddagger$ \\
\hline \multicolumn{5}{|l|}{ Parasit malaria (\%) } \\
\hline - Negatif & 86,0 & 86,7 & 86,4 & $0,954 \perp$ \\
\hline - Plasmodium falsiparum & 12,3 & 8,4 & 10,0 & \\
\hline - Plasmodium vivax & 1,8 & 4,8 & 3,6 & \\
\hline \multicolumn{5}{|l|}{ Kepadatan malaria (\%) } \\
\hline - Rendah & 89,5 & 94,0 & 92,1 & \\
\hline - Tinggi & 10,5 & 6,0 & 7,9 & $0,332 \ddagger$ \\
\hline \multicolumn{5}{|l|}{ Eosinofil (\%) } \\
\hline - Positif & 29,8 & 34,9 & 32,9 & \\
\hline - Negatif & 70,2 & 65,1 & 67,1 & $0,528 \ddagger$ \\
\hline
\end{tabular}


Tabel 2. Tabel silang faktor-faktor risiko kepadatan parasit malaria

\begin{tabular}{|c|c|c|c|c|}
\hline \multirow{2}{*}{ Variabel } & \multicolumn{2}{|c|}{ Kepadatan parasit malaria } & \multirow{2}{*}{$\begin{array}{l}\text { Rasio prevalens } \\
\quad \text { (IK 95\%) }\end{array}$} & \multirow[b]{2}{*}{$\mathrm{p}$} \\
\hline & Tinggi $(\mathrm{n}=11)$ & Rendah $(\mathrm{n}=129)$ & & \\
\hline \multicolumn{5}{|l|}{ Jenis kelamin } \\
\hline - Laki-laki & 6 & 51 & & \\
\hline - Perempuan & 5 & 78 & $0,5(0,2-1,9)$ & 0,514 \\
\hline \multicolumn{5}{|l|}{ Suku bangsa } \\
\hline - Sumba & 8 & 77 & & \\
\hline - Non Sumba & 3 & 52 & $0,6(0,1-2,2)$ & 0,597 \\
\hline \multicolumn{5}{|l|}{ Status gizi } \\
\hline - Gizi kurang & 10 & 78 & & \\
\hline - $\quad$ Gizi baik & 1 & 51 & $5,9(0,8-44,8)$ & 0,093 \\
\hline
\end{tabular}

objek lalu dilihat apakah ada telur cacing. Pemeriksaan kadar hemoglobin dan telur cacing dilakukan di Laboratorium RSUD Sumba Timur di Waingapu.

Analisis statistik menggunakan program SPSS 11,5 for Windows (SPSS Inc, USA). Digunakan uji $\chi^{2}$ untuk menguji kemaknaan hubungan apabila uji parametrik terpenuhi, sedangkan besaran risiko dinyatakan sebagai rasio prevalens. Analisis multivariat diuji dengan regresi logistik.

\section{Hasil}

Telah di lakukan penelitian pada 140 anak kelas IV dan V SD terdiri dari 57 anak laki-laki (rerata umur $11,7 \pm 1,36$ tahun) dan 83 anak perempuan (rerata umur 11,4 $\pm 1,36$ tahun) yang memenuhi kriteria inklusi dan setuju ikut dalam penelitian ini. Sebagian besar anak $(60,7 \%)$ berasal dari suku Sumba. Prevalensi gizi kurang didapatkan pada $63,6 \%$ anak dan keadaan ini tidak berbeda antara laki-laki dan perempuan. Dari pemeriksaan laboratorium tidak didapatkan parasit malaria pada $86,4 \%$ sampel darah tebal, dengan kepadatan parasit malaria rendah dan tidak ditemukan eosinofilia pada darah tepi. Tidak didapatkan perbedaan bermakna antara siswa laki-laki dan perempuan pada karakterisktik subjek. Data selengkapnya pada Tabel 1 .

Pada Tabel 2 terlihat bahwa tidak ada hubungan antara jenis kelamin, suku bangsa dan status gizi dengan kepadatan parasit malaria.

Pada Tabel 3 tertera kepadatan malaria yang tinggi merupakan faktor risiko terjadinya anemia
Tabel 3. Tabel silang antara kepadatan parasit malaria dengan anemia dan tidak adanya eosinofilia

\begin{tabular}{lcccc}
\hline & \multicolumn{3}{c}{ Kadar hemoglobin } & \multicolumn{2}{c}{ Eosinofilia } \\
\cline { 2 - 5 } & $\begin{array}{l}\text { anemia } \\
\mathrm{n}=65\end{array}$ & $\begin{array}{c}\text { normal } \\
\mathrm{n}=75\end{array}$ & $\begin{array}{c}\text { negatif } \\
\mathrm{n}=46\end{array}$ & $\mathrm{n}=94$ \\
\hline Kepadatan parasit malaria \\
- Tinggi & 10 & 1 & 9 & 2 \\
- Rendah & 55 & 74 & 37 & 92 \\
Rasio Prevalens (95\%IK) & $2,1(1,6-2,8)$ & $2,9(1,9-4,2)$ \\
nilai p & $\mathrm{p}=0,006^{*}$ & $\mathrm{p}=0,001^{*}$ \\
\hline $\mathrm{RP}=$ Rasio Prevalens & $\mathrm{IK}=$ Interval Kepercayaan \\
$*$ signifikan $\mathrm{p}<0,05$ &
\end{tabular}

(RP 2,1; 95\% IK 1,6-2,8 dan $\mathrm{p}=0,006)$. Juga didapatkan hubungan antara kepadatan parasit malaria dengan timbulnya eosinofilia. Subjek dengan kepadatan parasit malaria yang tinggi, 2,9 kali mempunyai risiko tidak terdapat respon eosinofilia pada darah tepi.

\section{Pembahasan}

Di daerah tropis, malaria masih merupakan penyakit yang menyebabkan morbiditas dan mortalitas tinggi khususnya pada anak. Dari penelitian di Kenya didapatkan bahwa prevalensi anak kurang gizi meningkat pada daerah endemis malaria dan penyakit yang menurunkan daya tahan tubuh lainnya. ${ }^{11}$ Malnutrisi akan menyebabkan kegagalan imunitas, 
menurunkan produksi antibodi sekretori IgA, fungsi fagosit, sistem komplemen, afinitas antibodi, dan produksi sitokin. ${ }^{19}$

Pada 140 anak usia sekolah dasar pada penelitian ini, prevalensi gizi kurang $66,7 \%$ pada laki-laki dan $61,4 \%$ perempuan. Rerata umur sekitar 11 tahun, berat badan pada laki-laki $(26,1 \pm 4,59) \mathrm{kg}$ dan anak perempuan $(26,5 \pm 4,93) \mathrm{kg}$ dan IMT anak laki-laki $(14,8 \pm 1,57) \mathrm{kg} / \mathrm{m}^{2}$ dan anak perempuan $(14,7 \pm 1,90)$ $\mathrm{kg} / \mathrm{m}^{2}$. Menurut kurva NCHS CDC 2000, rerata IMT berada di bawah persentil ke-5 dan termasuk dalam kriteria gizi kurang, ${ }^{16}$ maka rerata subjek yang diteliti mempunyai status gizi kurang. Rerata tinggi badan $(132,5 \pm 8,68) \mathrm{cm}$ untuk anak laki-laki dan $(133,9 \pm 7,91) \mathrm{cm}$ dan perempuan berada di bawah persentil ke-3 menurut kurva NCHS CDC 2000 yang berarti bahwa rerata subjek adalah berperawakan pendek. Hal ini sesuai dengan penelitian di Kenya bahwa di daerah endemis malaria banyak didapatkan anak dengan perawakan pendek yang merupakan gambaran malnutrisi kronis. ${ }^{11,12}$

Sebagian besar subjek berasal dari etnis Sumba dan sisanya berasal dari suku non Sumba (Flores, Timor, Sabu, dan Jawa). Kepadatan parasit malaria menunjukkan interaksi antara plasmodium (merozoit) dan eritrosit pejamu. Secara genetik ada faktor pejamu seperti haptoglobin dan erythrocyte-binding antigen plasmodium yang berperan dalam interaksi antara host dan pejamu, dan interaksi ini tidak semata-mata disebabkan faktor suku. ${ }^{20,21}$

Hampir setengah subjek mengalami anemia, subjek dengan anemia lebih besar pada anak laki-laki $(54,4 \%)$ dibandingkan dengan perempuan $(42,2 \%)$. Malaria dapat menyebabkan anemia nutrisional, berdasar fakta yang menunjukkan bahwa parasitemia persisten atau rekuren dapat mengakibatkan anemia defisiensi besi, yang diduga terjadi melalui penurunan absorpsi besi, penurunan pembentukan kompleks haptoglobin hemoglobin yang mengakibatkan penurunan avaibilitas besi, dan melalui perantaraan sitokin yang menekan hematopoeisis. ${ }^{22}$ Penelitian di Afrika memperlihatkan bahwa prevalensi anemia pada anak balita 69\% dengan 67\% di antaranya merupakan anemia defisiensi besi, ${ }^{23}$ dan kadar hemoglobin akan semakin turun pada anak yang sering mendapatkan serangan malaria dan anak dengan kegagalan terapi malaria. ${ }^{22}$

Pemeriksaan darah tebal pada sebagian besar tidak didapatkan parasit malaria. Pada subjek dengan parasit malaria positif, sebagian besar menampakkan gambaran plasmodium falsiparum. Ini sesuai dengan penelitian di Tanzania, ${ }^{22}$ Kenya, Papua New Guinea ${ }^{6}$ dan beberapa negara lain di Afrika. ${ }^{1}$ Didapatkan 10,5\% anak lakilaki dan 6,0\% anak perempuan mempunyai densitas/ kepadatan malaria tinggi. Di Zanzibar didapatkan prevalensi plasmodium falsiparum dengan kepadatan tinggi (di atas 5000 parasit $/ \mu$ darah) di bawah $1 \%{ }^{24}$ Pemeriksaan darah tebal seperti pada penelitian ini tidak terlalu sensitif untuk mendeteksi kepadatan parasit malaria. Hasil ini mendukung teori semi imunitas yaitu pada daerah dengan endemisitas tinggi, kepadatan parasit malaria yang sangat tinggi hanya timbul pada penderita dengan demam karena serangan malaria. Pasien lain umumnya tidak memperlihatkan gejala (asimtomatis) walau didapati parasit dalam sediaan darahnya (parasitemia kronis), ${ }^{25}$ atau dijumpai parasit dengan kepadatan rendah. ${ }^{26,27}$ Dengan demikian kepadatan parasit malaria bukan merupakan pemeriksaan baku emas untuk diagnosis malaria. ${ }^{28}$

Dari review sistematik beberapa penelitian yang dikutip Shankar ${ }^{1}$ dan di Kenya ${ }^{12}$ didapatkan bahwa anak yang kurus atau pendek karena malnutrisi mempunyai risiko 1,2 kali sampai 1,57 kali terinfeksi malaria. Hal ini disebabkan respon imun terhadap antigen malaria rendah pada anak dengan gizi kurang. Pada penelitian ini tidak didapatkan hubungan antara status gizi dengan kepadatan parasit malaria (RP 5,9 $95 \%$ IK 0,8-44,8; $\mathrm{p}=0,093)$. Ini sesuai dengan penelitian di Vanuatu yang mendapatkan anak dengan malnutrisi sedang dan berat meningkat risikonya untuk terinfeksi malaria walaupun hasilnya tidak signifikan (OR 1,3; 95\% KI 0,92-1,88) yang mungkin disebabkan adanya peran beberapa mikronutrien seperti besi, seng, dan vitamin A dalam imunitas terhadap malaria. ${ }^{2}$ Pada Tabel 2 tampak bahwa tidak didapatkan hubungan antara jenis kelamin dengan kepadatan parasit malaria. Hasil ini tidak sesuai dengan penelitian di Ghana yang memperlihatkan bahwa risiko terinfeksi meningkat pada anak laki-laki sebesar 2,16 kali. ${ }^{29}$

Infeksi malaria walaupun asimptomatis akan menurunkan kadar hemoglobin yang antara lain disebabkan karena hemolisis pada sel darah merah. Penelitian di Kenya pada anak balita memperlihatkan perbedaan kadar hemoglobin sebesar 1,1 g/dl lebih rendah pada anak dengan malaria dibandingkan kontrol. ${ }^{23}$ Pada penelitian ini risiko anemia akan meningkat 2,1 kali pada subjek dengan kepadatan parasit malaria tinggi (Tabel 3). Hasil ini sesuai dengan 
penelitian di Tanzania yaitu pada anak dengan kepadatan parasit malaria tinggi dijumpai kadar hemoglobin $<0,97 \mathrm{~g} / \mathrm{dl}$ dibandingkan anak dengan kepadatan parasit malaria rendah. ${ }^{22}$ Di Ghana didapatkan bahwa risiko anemia meningkat pada anak dengan infeksi plasmodium falsiparum, anak laki-laki, dan pada umur yang lebih muda. ${ }^{29}$

Dari Tabel 1 tertera bahwa sebagian besar subjek tidak menampakkan eosinofil atau eosinofil kurang dari 3\% dalam darah tepinya. Beberapa keadaan atau penyakit penyebab atau berhubungan dengan eosinofilia seperti alergi dan infeksi parasit, walaupun perannya lebih banyak dilaporkan pada infestasi cacing. ${ }^{9} 10$ Keterbatasan dalam penelitian ini adalah peran infestasi cacing terhadap eosinofilia hanya dilakukan berdasarkan anamnesis dan pemeriksaan feses 1 kali. Untuk menyingkirkan infestasi cacing seharusnya pemeriksaan feses dilakukan 3 kali berturut-turut. ${ }^{26}$

Respon imun terhadap malaria ditandai oleh dominasi aktivitas sel T helper 2 (Th2) pada infeksi kronis dan T helper 1 (Th1) pada respon awal pada infeksi akut. Sel Th2 akan meproduksi beberapa sitokin akibat infeksi malaria seperti IL-4, IL-5, IL-6 dan IL10 dengan dominasi IL-5. Peningkatan IL-5 yang dihasilkan oleh sel Th2 yang dominan pada infeksi kronis diduga berperan terhadap terjadinya eosinofilia pada infeksi malaria di daerah endemis. ${ }^{10}$ Beberapa penelitian memperlihatkan bahwa eosinofilia tidak muncul sampai beberapa minggu setelah terapi malaria, dan mengalami puncaknya pada 4-8 minggu setelah terapi. Penelitian di Thailand memperlihatkan bahwa eosinofilia mencapai puncaknya pada akhir minggu pertama setelah terapi. ${ }^{14}$ Penelitian Sarjono yang dilakukan di Bangkok justru mendapatkan infeksi malaria dapat menurunkan jumlah eosinofil darah tepi secara bermakna. ${ }^{30}$ Demikian juga penelitian di Ghana memperlihatkan eosinofil menurun pada fase akut penyakit. ${ }^{9} \mathrm{Hal}$ ini sesuai dengan penelitian ini yaitu kepadatan parasit malaria yang tinggi mempunyai risiko 2,9 kali untuk menurunkan atau menyebabkan tidak adanya eosinofilia dalam darah tepi.

\section{Kesimpulan dan saran}

Sebagian besar anak usia sekolah dasar pada penelitian ini mempunyai status gizi kurang dan perawakan pendek yang merupakan gambaran malnutrisi kronik.
Tidak didapatkan parasit malaria dan eosinofilia pada sebagian besar kasus. Seperti pada daerah endemis malaria lainnya, pada penelitian ini tidak didapatkan kepadatan parasit malaria yang tinggi. Kepadatan parasit malaria tidak berhubungan dengan jenis kelamin, suku bangsa dan status gizi, tetapi kepadatan parasit malaria yang tinggi akan meningkatkan risiko anemia 2,1 kali dan tidak adanya respon eosinofilia 2,9 kali. Penelitian ini dilakukan pada musim hujan, akan lebih baik bila dilakukan pula penelitian kepadatan parasit malaria pada musim kemarau dan hubungannya dengan respon eosinofilia pada fase akut serangan malaria.

\section{Ucapan terima kasih}

Peneliti mengucapkan terima kasih kepada Dr. Matius, SpBD Kepala Dinas Kesehatan Kabupaten Sumba Timur; Dr. Leli, Kepala Puskesmas Melolo Kabupaten Sumba Timur Nusa Tenggara Timur; dan Prof. Takafumi Ishida, PhD, Department of Human Biology and Genetics, Graduate School of Science, University of Tokyo Japan.

\section{Daftar Pustaka}

1. Shankar AH. Nutritional modulation of malaria morbidity and mortality. J Infect Dis 2000; 182(Suppl 1):37-53

2. Caulfield LE, Richard SA, Black RE. Undernutrition as an underlying cause of malaria morbidity and mortality in children less than five years old. Am J Trop Med Hyg 2004; 71(Suppl 2):55-63

3. Dinas Kesehatan Kabupaten Sumba Timur. Penyakit malaria di Kabupaten Sumba Timur Tahun 2001.

4. Gunawan S. Epidemiologi malaria. Dalam: Harijanto PN (ed). Malaria. Epidemiologi, patogenesis, manifestasi klinis dan penanganan, Jakarta: penerbit EGC; 2000. h. $1-16$

5. Genton B, Al-Yaman F, Ginny M, Taraika J, Alpers MP. Relation of anthropometry to malaria morbidity and immunity in Papua New Guinean children. Am J Clin Nutr 1998; 68:734-41.

6. Shankar AH, Genton B, Baisor M, Paino J, Tamja S, Adiguma T, dkk. The influence of zinc supplementation on morbidity due to Plasmodium falciparum: a randomized trial in preschool children in Papua New Guinea. Am J Trop Med Hyg 2000; 62:663-9 
7. Ditjen Bina Kesehatan Masyarakat Depkes RI. Gizi dalam angka, sampai dengan tahun 2003. Jakarta: Depkes RI. 2005

8. MacDonald SM, Bhisutthibhan J, Shapiro TA, Rogerson SJ, Taylor TE. Immune mimicry in malaria: Plasmodium falciparum secretes a functional histamine-releasing factor homolog in vitro and in vivo. PNAS 2001; 98: 10829-32

9. Kurtzhals JAL, Reimert CM, Tette E, Dunyo SK, Koram KA, Akanmori BD, dkk. Increased eosinophil activity in acute plasmodium falciparum infection association with cerebral malaria. Clin Exp Immunol 1998; 112:303-7

10. Malguamera L, Musumeri S. The immune response to plasmodium falciparum malaria. Lancet Infect Dis 2002; 2:472-8

11. Kwena AM, Terlouw DJ, De Vlas SJ, Phillips-Howard PA, Hawley WA, Friedman JF, dkk. Prevalence and severity of malnutrition in pre-school children in a rural area of Western Kenya. Am J Trop Med Hyg 2003: 68(Suppl 4):94-9

12. Nyakeriga AM, Troye-Blomberg M, Chemtai AK, Marsh K, Williams TN. Malaria and nutritional status in children living on the coast of Kenya. Am J Clin Nutr 2004; 80:1604-10.

13. Ditjen Pemberantasan Penyakit Menular dan Penyehatan Lingkungan Depkes RI. Panatalaksanaan kasus malaria di Indonesia. Depkes RI. 2002:2-12.

14. Camacho LH, Wilairatana P, Weiss G, Mercader MA, Brittenham GM, Looareesuwan S, Gordeuk VR. The eosinophilic response and haematological recovery after treatment for plasmodium falciparum malaria. Trop Med Int Health 1999; 4:471-5

15. Belizzi MC, Dietz WH. Workshop on childhood obesity: summary of the discussion. Am J Clin Nutr 1999:(70 Suppl):173-5

16. WHO. Physical status: the use and interpretation of anthropometry. WHO. Geneva: WHO;1995: 263-313

17. Pribadi W. Parasit malaria. Dalam: Parasitologi Kedokteran. Jakarta: BP FK UI;2000. h. 171-206

18. Soemantri A, Tamam M. Hematologi-Onkologi. Dalam: Hartantyo I, Susanto R, Kosim S, Wastoro D. Pedoman Pelayanan Medik Anak. Bagian Ilmu Kesehatan Anak FK Undip/SMF RSUP Dr Kariadi. Edisi-2, Semarang: 1997.

19. Krishna S. Science, medicine, and the future: malaria. BMJ 1997; 315:730-2
20. Fowkes FJI, Imrie H, Migot-Nabias F, Michon P, Justice A, Deloron P. Association of haptoglobin levels with age, parasite density, and haptoglobin genotype in a malaria-endemic area of Gabon. Am J Trop Med Hyg 2006; 74:26-30

21. Toure FS, Bisseye C, Mavoungou E. Imbalanced distribution of plasmodium falciparum EBA-175 genotypes related to clinical status in children from Bakoumba Gabon. Clin Med Res 2006; 4:7-11

22. Ekvall H, Premji Z, Bennett S, Bjorkman A. Hemoglobin concentration in children in a malaria holoendemic area is determined by cumulated plasmodium falciparum parasite densities. Am J Trop Med Hyg 2001; 64:58-66

23. Verhoef H, West CE, Ndeto P, Burema J, Beguin Y, Kok FJ. Serum transferrin receptor concentration indicates increased erythropoiesis in Kenyan children with asymptomatic malaria. Am J Clin Nutr 2001; 74:767-75

24. Rebecca J, Stoltzfus, Hababu M, Chwaya, Albonico M, Kerry J, dkk. Serum ferritin, erythrocyte protoporphyrin and hemoglobin are valid indicators of iron status of school children in a malaria-holoendemic population. J Nutr 1997; 127:293-8

25. Bejon P, Andrew L, Hunt-Cooke A, Sanderson F, Gilbert SC, Hill AVS. Thick blood film examination for Plasmodium falciparum malaria has reduced sensitivity and underestimates parasite density. Malar J 2006; 5:104. Didapat dari: URL:http://www.malariajournal.com/ content/5/1/104

26. Curnutte J. Disorders of granulocyte function and granulopoiesis. Dalam : Nathan DG, Oski FA. Hematology of infancy and childhood. Edisi ke-4. Philadelphia: WB Saunders; 1993.h. 904-77

27. Prybylski D, Khaliq A, Fox E, Sarwari AR, Strickland GT. Parasite density and malaria morbidity in the Pakistani Punjab. Am J Trop Med Hyg 1999; 61:791-801

28. Delley V, Bouvier P, Breslow N, Doumbo O, Sagara I, Diakite $\mathrm{M}$, dkk. What does a single determination of malaria parasite density mean? A longitudinal survey in Mali. Trop Med Int Health 2000;5:404-12

29. Ronald LA, Kenny SL, Klinkenberg E, Akoto AO, Boakye I, Barnish G, Donnelly MJ. Malaria and anaemia among children in two communities of Kumasi, Ghana: a crosssectional survey. Malar J 2006; 5:105 Didapat dari: URL:http://www.malariajournal.com/content/5/1/105

30. Sarjono WT. Perbedaan jumlah eosinofil darah tepi pada penderita pengidap infeksi cacing usus dan malaria. Maj Kedok Indon 1999; 49:43-7 